\title{
Creativity and the Ownership of English: the Teaching and Assessment of Creative Writing with Non-Native Speakers
}

\author{
IAN POPLE \\ University of Manchester
}

Received: 28 February 2013 / Accepted: 14 June 2013

ISSN: $1697-7467$

\begin{abstract}
This article examines some aspects of the relationship between the ownership of English language and its production by non-native speaker creative writers. It discusses ways in which novice creative writers may strive to control their production of text in English, without the scaffolding and structures that conventional 'academic writing' may both offer and impose. The article also discusses the relationship between the students attempts to control and own the English language, and the ways in which the academic assesses their writing; both in terms of their creativity and their control. Keywords: Creative Writing; ownership; assessment; second language writing.
\end{abstract}

Creatividad y apropiación de la lengua inglesa: la enseñanza y evaluación de creación literaria a estudiantes no nativos

RESUMEN: Este artículo abarca algunos aspectos correspondientes a la relación entre apropiación de la lengua inglesa y su producción por parte de escritores no nativos de literatura creativa. También se analizan diferentes maneras en las que escritores novatos se esfuerzan por alcanzar un control de los textos producidos en inglés, sin el andamiaje y las estructuras que la escritura académica les podría ofrecer y al mismo tiempo, imponer. Este artículo también profundiza en la relación entre el esfuerzo por parte de los estudiantes por controlar y apropiarse de la lengua inglesa, y la manera en que el sistema académico evalúa sus textos, en términos de creatividad y control.

Palabras claves: creación literaria: apropiación, evaluación, escritura en segunda lengua.

For the past six years, the Language Centre at the University of Manchester has offered credit-based modules in Creative Writing to visiting and exchange students. These students may be speakers of European languages, but the modules also attract students from Korea and Japan. Many of these students have not written creatively before. There are some students who have written, but who have received little in the way of feedback, and whose writing has been personal and often 'secretive'. None of these writers have formally studied creative writing at university level.

These facts suggest that these writers are, as I have termed elsewhere, 'neophytes' (Pople, 2008). As a result of this, and the fact that they are writing in a language that is not their 'own', a classroom is created which is always interesting and challenging for the 
tutor. Such writers need care and nurturing, which is not to feed the ego of the tutor, or to build unnecessary pieties into the pedagogy. However, it suggests that tutor interventions need staging and that structures need to be made entirely clear to the students. This is particularly true of assessment. Assessment is still the subject of much debate amongst teachers of creative writing in higher education in the UK, who work, in the main, with native speakers. It is more so when the assessment structures of a British university does not mesh with the assessment structures of a European student. An example of this is the student who was reduced to tears of rage because the marking bell-curve of the university restricted her mark to 76 , the highest in the class, when she expected scores in the nineties from her German university! In part, the substructure of assessment and the process that leads up to assessment, is one of the concerns to this article.

In addition, I would like this article to reflect aspects of the contemporary debate on the 'ownership' of English. As Crystal puts it so clearly,

$\ldots$ if there is one predictable consequence of a language becoming a global language, it is that nobody owns it any more. Or rather, everybody who has learned it now owns it - 'has a share in it' might be more accurate - and has the right to use it in any way they want' (Crystal, 2003: 2-3).

Of course, we need to define 'ownership' here, and Crystal' s comment about 'sharing' is a way of backing away from the details of that debate. Chinua Achebe adds another dimension of agency to this account:

The price a world language must be prepared to pay is submission to many different kinds of use. The African writer should aim to use English in a way that brings out his message best without altering the language to the extent that its value as a medium of international exchange will be lost. He should aim at fashioning out an English which is at once universal and able to carry his peculiar experience (cited in Jenkins, 2009:193).

In the hands of the finest creative writers, then, the language submits to the needs of the writer. Yet, Achebe, too, has a caveat to the sense of the language's submission. The writer, too, needs to have sensitivity to the needs of a larger audience; that the writer be both local and in W.H.Auden's words 'prized everywhere'. The writer is in a dialogue with the language that I will explore more below.

For the non-native students on Creative Writing courses, the need to come to terms with owning English is a real one. This is a need predicated on the essentially non-transactional nature of their working with English. In their creative writing, there is no shaping of the text towards a practical outcome. The students are not performing the communicative functions that language teaching and learning has taught for so long, i.e, 'making polite requests', 'offering and refusing offers'. Neither are they performing the academic functions that genre analysis has adumbrated in English for Academic Purposes. Thus the pragmatic structures of transactional language use are withdrawn. And this means that ownership of English as an L2, I would suggest, is particularly raw, and unalloyed by context. 
Bakhtin comments on this in the following;

"Our speech, that is, all our utterances (including creative works), is filled with others' words, varying degrees of otherness or varying degrees of 'our own-ness', varying degrees of awareness and detachment. These words of others carry with them their own expression, their own evaluative tone, which we assimilate, rework and re-accentuate" (Bakhtin, 1986: 89).

Bakhtin assumes that there actually is a sense of cultural otherness and 'own-ness' in the dialogue. However, for the creative writer in a second or third language, the raw and unalloyed nature of that dialogue is particularly intense without the support that transactional language will provide. Here, the creative writer, herself, 'creates' and negotiates that support and scaffolding as she proceeds. And that scaffolding may include a range of cultural, personal and interactional elements which will emerge from the needs of the writer and the writing.

Foucault, in 'What is an Author', also reminds us that there has been a switch in ideas of ownership between creative and transactional writing. He points out that in the early evolution of creative texts there was less emphasis on an author's name being attached to a text. In the sixteenth and seventeenth centuries, however, scientific discourse became less attached to its author.

[The author's] membership in a systematic ensemble, and not the reference to the individual who produced them, stood as their guarantee. The author function faded away, and the inventor's name served only to christen a theorem, proposition, particular effect, property, body, group of elements, or pathological syndrome. By the same token, literary discourses came to be accepted only when endowed with the author function (Foucault, 1969).

Thus, we partly expect our student writers respond to the exactitudes of an academic discourse community, with its own handle upon a particular tiller of language. And, on the other hand, we wish them to be original, to think for themselves, to adopt critical, and therefore, independent academic literacies.

Even the greatest writers in the language are not immune from that intensity for 'correct' ownership, and the forces that play upon it. When Vladimir Nabokov started to publish in America in the 1940s, his 'friend', the literary critic, Edmund Wilson commented as follows, 'I hope that you will get someone at Wellesley to read your proofs. - because there are a few, though not many mistakes in the English'. And Wilson never really let that facet of Nabokov's English go. In 1950, he wrote, '...in spite of some errors, Mr Nabokov's mastery of English almost rivals Joseph Conrad's'(cited in Jin, 2010: 462). As Jin suggests, 'In spite of Wilson's extraordinary generosity to his friend, he was also a pain in Nabokov's neck' (ibid). Nabokov was evidently stung by the comparison with Conrad, retorting, 'Conrad know how to handle readymade English better than I; but I know better the other kind. He never sinks to the depths of my solecisms, but neither does he scale my verbal peaks' (Jin, 2010: 463). By this he means conventional English and cliché, and perhaps also what contemporary linguistics would call 'fixed phrases', and which Nabokov explicitly rejected (ibid).

The avoidance of cliché is something that is directly assessed among the criteria used with the Creative Writing students on this course; and the range of those criteria are below: 
Assessment criteria:

\begin{tabular}{|c|c|c|c|c|c|c|}
\hline & Accuracy & $\begin{array}{l}\text { Artistic } \\
\text { control of } \\
\text { Language }\end{array}$ & Observation & Structure & Voice & $\begin{array}{l}\text { Commen- } \\
\operatorname{tary} / \text { Analysis }\end{array}$ \\
\hline $\begin{array}{l}D \\
e \\
f \\
i \\
n \\
i \\
t \\
i \\
o \\
n \\
s\end{array}$ & $\begin{array}{l}\text { Technical } \\
\text { control of } \\
\text { grammar } \\
\text { and vocabu- } \\
\text { lary }\end{array}$ & $\begin{array}{l}\text { Control of } \\
\text { the language } \\
\text { - especially } \\
\text { adjectives, } \\
\text { adverbs and } \\
\text { cliché }\end{array}$ & $\begin{array}{l}\text { The dis- } \\
\text { cerning of } \\
\text { details which } \\
\text { render situa- } \\
\text { tions vivid } \\
\text { to the reader; } \\
\text { the principle } \\
\text { of 'showing- } \\
\text { not-telling' }\end{array}$ & $\begin{array}{l}\text { The orga- } \\
\text { nisation of } \\
\text { text with the } \\
\text { needs of gen- } \\
\text { re, reader, } \\
\text { content and } \\
\text { economy in } \\
\text { mind }\end{array}$ & $\begin{array}{l}\text { Control of } \\
\text { narrative } \\
\text { voice dialo- } \\
\text { gue, register } \\
\text { and tone; } \\
\text { may well be } \\
\text { 'achieved' } \\
\text { as against } \\
\text { 'innate' } \\
\text { and, thus, } \\
\text { is linked to } \\
\text { observation. }\end{array}$ & $\begin{array}{l}\text { The student's } \\
\text { own explo- } \\
\text { ration of } \\
\text { their writing } \\
\text { portfolio } \\
\text { and which } \\
\text { engages with } \\
\text { the four other } \\
\text { assessment } \\
\text { criteria }\end{array}$ \\
\hline $1^{\text {st }}$ & $\begin{array}{l}\text { Contains } \\
\text { one or two } \\
\text { minor inac- } \\
\text { curacies and } \\
\text { shows fully } \\
\text { appropriate } \\
\text { command } \\
\text { of cohesive } \\
\text { devices in } \\
\text { English }\end{array}$ & $\begin{array}{l}\text { Language fu- } \\
\text { lly controlled: } \\
\text { fully particu- } \\
\text { larised use of } \\
\text { language that } \\
\text { shows com- } \\
\text { plete control } \\
\text { of selectivity, } \\
\text { originality } \\
\text { and editing of } \\
\text { language at } \\
\text { all stages of } \\
\text { the text. }\end{array}$ & $\begin{array}{l}\text { Full control } \\
\text { and use of } \\
\text { observed } \\
\text { detail. }\end{array}$ & $\begin{array}{l}\text { Fully explo- } \\
\text { res creative } \\
\text { possibilities } \\
\text { and eco- } \\
\text { nomies of } \\
\text { structure. }\end{array}$ & $\begin{array}{l}\text { Full control } \\
\text { of narrative } \\
\text { voice and } \\
\text { dialogue; } \\
\text { complete } \\
\text { awareness } \\
\text { of demands } \\
\text { of tone and } \\
\text { register; } \\
\text { effective } \\
\text { use of idiom } \\
\text { where } \\
\text { necessary. }\end{array}$ & $\begin{array}{l}\text { A full } \\
\text { exploration of } \\
\text { the redrafting } \\
\text { and editing } \\
\text { processes; } \\
\text { showing this } \\
\text { in thorough } \\
\text { analysis of } \\
\text { those proces- } \\
\text { ses. Comple- } \\
\text { tely engages } \\
\text { with the other } \\
\text { criteria of } \\
\text { assessment. }\end{array}$ \\
\hline
\end{tabular}

The reader will note, I hope, the attempt to provide a high level of explicitness about the marking criteria. As I have mentioned above, assessment of Creative Writing in Higher Education is somewhat less of a 'hot potato' than it once was. But the assessment of 'creativity' is always going to be difficult, with a difficulty that will never go away. The larger artistic community constantly reassesses the creative efforts of artists both past and contemporary; a reassessment born of the way societies and cultures change. We want different things from different artists at different moments in history. The artists, whose reputations have been maintained over the years and centuries, are those who, by definition, remain contemporary! 
In the academy, however, owing to the assessment regimes of the university, it is necessary to particularise elements of creative production which 'can' be assessed. As can be seen, I am sure, these assessed elements themselves are not unproblematic. Whereas, the technical proficiency in English of such students might be relatively easily ascertained, their sense of 'voice', and 'structure' might not seem so accessible or assessable. How does a neophyte writer gain a voice? How does a neophyte write learn to handle structure; particularly when the students are, generally, only on the course for ten weeks? In these circumstances, the students may have to rely on the experience as both language tutor and creative writer of the tutor; in this case, me.

The other important aspect of these criteria is that they measure control; in ways that are analogous to the criteria employed to measure proficiency in language learning. In three out of the five criteria, control is explicitly expected. In two others, 'accuracy' and 'structure', control is implied. Of course, for a number of the students on this course, perhaps those operating at $\mathrm{C} 1$ or even B2 level, such control may be very difficult. For example, the sheer lack of vocabulary may inhibit a student from fully realising a scene that they are visualising and imagining. However, as I hope we will see below, that may not inhibit the play of the imagination. So there may be areas in all this in which the student does not have complete control, but they may be able to own material in other ways.

\section{StUdent WRiting AND OWNERShip}

In this next section, I will examine four examples of student writing produced on the course. In analysing this writing, I will try to suggest the ways in which student, neophyte writers may be seen to be moving to a sense of ownership in English. What is important here is that ownership in English does not always imply technical correctness.

This first piece came from the very first session with the group. I try to emphasis observation with these students because I suspect that people coming to creative writing for the first time have 'large' ideas about writing, which need correctives. By this I mean that for a student might well come into the creative writing classroom thinking that they might need both a large imagination and a knowledge of the technical constituents of a sonnet, say. To counter that 'large' idea about writing, I often get the students to look closely at rather common place objects around the class room. This was Pau's response to one such gaze:

\section{Pau:}

The door is giving you, finally, an incentive, a slight motivation. You have to hold fast to these pleasant signs of life outside the room and keep pulling. A new world will open just in front of you, full of light and colours. But don't let this siren song distract you! Now, you are out, but you still have to escape the door. It's coming back and it wants to take revenge. You have to move quickly but, don't worry; a simple step forward would be enough. The only thing the door has left is to launch an angry call in the form of a big slam, but it is useless. You have won the battle.

What Pau claims ownership of here is interaction with the door; a rather commonplace idea that the student works interesting and quite adroitly. Firstly, Pau is describing the way 
the door is fitted with a spring and needs pushing to open and from which to leave the class room. He opens that experience out by using the second person, which in English as the advantage of floating between a direct singular and an encompassing plural. And into that floating 'you', the writer pulls not only the sensuality of the interaction, but also a kind of distance from the physicality of opening the door. The only physical indication here is 'keep pulling', all the other handlings of the door are implied. And what is layered on top of this are more psychological interactions with; 'distract', 'escape', 'revenge', 'launch an angry call'. Thus Pau's control is to wrest the physical away so that it does not only engage with the empirical but also with the way the person engages with a partially personified door. That control of the physical can only be encoded in the language. And the language, if a little stilted, is highly technically accurate. It is a tool that has been worked on so that it can fulfil the purposes this user demands of it.

The next example here comes from Teddy, whom I still regard as the most creatively gifted of the students, who have attended the course. Teddy's gift was to detail and evoke a world into which the reader was drawn with a particular kind of inevitability. What Teddy did not have was a full ownership of the technical resources of English; that is, his grammar and, to some extent, his lexicon was weak; as will be seen from the following extract.

\section{Teddy:}

The door car opens, two foots with black varnish shoes appears and run to the hall door. Fife avails oneself of rolling to a hedge. His father come back in the same time, without seeing his son. The car goes over the street...

Fife waits a few instant and goes round the house. Arrived in the front of his bedroom, he climbs the wall and enter in. He brings out the paper from his pocket. He cut out with chisels and put this on the bin. Sits on the bed, he stays, inanimate and realizes his brother left...

Even a cursory glance at this shows how weak Teddy's grammar is: 'two foots', 'appears and run', 'avails oneself of rolling to...'; there is no need to go on. Almost every phrase is technically flawed. But beyond that is a considerable amount of evidence that Teddy is deep inside the imagined world he has created. The first instance of this is in the first sentence where the 'two foots' are metonymic of Fife, the protagonist in this extract. And this sense of the metonymic occurs later when he writes 'The car goes over the street.', where the father is driving the car. In addition to that sense of the metonymic is the sheer pace of the narrative. In the second paragraph here, there is narrative and little else; in this paragraph, there are only two adjectives, 'few' and 'inanimate'. Teddy is fully immersed in this story, giving it considerable momentum, with his 'simple', mostly SVO sentences. So, as I have suggested above, Teddy owns the narrative, and, I would suggest, owns a sense of his own voice here; a pared, honed voice in English, which carries the narrative and the imagination which fuels that narrative. And possibly, creative fiction doesn't actually need much more than that kind of ownership. Thus, Teddy scores highly in the categories for both voice and structure, where his structure is highly economic and the voice strongly controls that economy.

In the next extract, the writer most clearly owns the space around the authorising consciousness of the writing. By 'authorising consciousness', I mean the 'self' which owns and 
controls both the imagination and the creativity of final piece of writing (see O'Neill, 1997). And, although it is true that Teddy is clearly the 'authorising consciousness' of his piece, in Jingqiao's text, the writer allows us to assume that the authorising voice and the I of the writer are co-terminous, so that we might consider this to be 'autobiographical' writing.

\section{Jingqiao:}

My mum used to tell me that I slept every night with my sweet felt doll when I was a baby. I remember when its little black nose made with a button was unstitched. I cried and cried because I thought it could not breathe anymore and it would die. I also remember how I spent hours playing with it. I had a lot of toys, but I got bored of all but this charming bear. I imagined each day a new identity for my plushy friend. That is the reason why it has no name.

Jingqiao allows us to assume that the writer and I are one and the same because the focus of the writing is on personal lived experience. Jingqiao's interaction with the doll/bear is focused on the 'I's cognitions in the verbs 'remember', 'thought', 'imagined', 'bored'. Thus the reader is taken into an elaborately constructed inner world; perhaps the world of the child who plays with the toy, or, perhaps the world that exists in the stasis of the remembered autobiography. All of the sentences begin with 'I' apart from the first and the last; the first sentence begins with 'my', and thus brings the reader into the authorising consciousness via the mother. The last sentence offers a final judgement on the identity of the toy.

In terms of ownership and assessment, the ownership is not the voiced solipsism of the writer, although that controls the adjectives which comment on the bear; 'sweet felt', 'charming', 'plushy'. The technical level of the English is good, robust and effective. And the text is neatly structured from the mum in the beginning through the narrative voice in the middle to the final conclusion around the bear itself; from the physical engagement with the bear at the beginning to the time spend in the bear's company. Although the piece may be seen as solipsistic, it is beguiling and the relationship between owner and toy is deftly drawn.

In the next text, Benedetta has taken the same exercise of writing about an object in the classroom as Pau in text one. Her response is not a personal engagement with the objects; her response is to personify the clock and the fire alarm in the room and create a story about them.

\section{Benedetta}

His hands had turned round many and many times (about 69 thousand) and winter had got by. That's when Clockice, just sprouting like a bud kissed by the first warm ray of sunshine, woke-up happy and decided to invent Time. By doing so, Squawkly had said to him, he would have allowed every living being to make calculations, even to count their lives' periods and, most importantly, to be able to answer to that fateful question.

The technical accuracy of this text is not perfect; we can see this in the second line with 'got by', rather than gone by'; and 'their lives' periods rather than the'periods of their lives'. This last phrase seems enigmatic even in the context of the clock and the fire alarm. But there are other elements such as the control of syntax and sentence structure, which, if 
not perfect, are sophisticated. This is true even of the final sentence in this extract; which is rendered clumsy by its length and the confusions of the 'him' and 'he' at the beginning. However, it is ambitious, and part of its ambition is to render vivid the inner world of the personified fire alarm. So the text attempts to observe the inner life of a character and make that come alive for the reader; even if the syntax tangles rather in the attempt. In this, the writer is less successful than the writer of text 2, whose direct, even curt text pulls the reader along within the vision. In text 4 , the writer attempts to recreate the entanglements of consciousness, and succeeds only to her own detriment, perhaps.

\section{Conclusion}

In this article, I have examined the ways in which novice creative writers working in a second, or even third language, are working towards owning English. I have suggested that they are doing this without the scaffolding of transaction or genre, or without the scientific discourse community which allows them a kind of Foucauldian anonymity. The French feminist, Helene Cixous posits a development of the writer. At the beginning, a writing identity has to be created; in the second stage, the writing ' $\mathrm{I}$ ' is not erased completely but withdraws and in withdrawing creates a space or site where the voices of others may be heard. It may be, perhaps, that, into this second stage, the academic discourse community exerts its pressures and needs.

In the writing we have looked at here, the writers are, for the most part, in stage one of Cixous's evolution. But in that stage, they are learning to find an identity and voice in a second language. Although this article has provided just a tiny sample of writing that has been produced over the six years since the course started, I hope that I have suggested that creative writing in a second language has real value in the pedagogy of Second Language Learning. And that it has this value through the ways in which it allows these learners to work inside the language and to discover their individual and particular ways of owning it.

\section{BiBLIOGRAPHY}

Bakhtin, M.M. (1981). The Dialogic Imagination: Four Essays M.Holquist (ed.), Austin: University of Texas Press.

Cixous, H. (1989). "From the Scene of the Unconscious to the Scene of History", in The Future of Literary Theory, R. Cohen (ed.), London: Routledge, 1-18.

Crystal, D. (2003). English as a Global Language, $2^{\text {nd }}$ ed., Cambridge: Cambridge University Press.

Foucault, M. (1969). 'What is an Author' available from: https://wiki.brown.edu/confluence/download/attachments/74858352/FoucaultWhatIsAnAuthor.pdf, accessed 13 February, 2013.

Ha Jin. (2010). "In Defense of Foreignness", in A. Kirkland (ed.) The Routledge Handbook of World Englishes, London: Routledge, 461-470.

O' Neill, M. (1997). Romanticism and the Self-Conscious Poem, Oxford: Clarendon Press.

Pople, I.S. (2009). "Towards an Ontology of Neophyte Writing”, in New Writing: The International Journal for the Practice and Theory of Creative Writing, 6, 1: 27-34. 